\title{
Curtin University
}

\author{
Rachel Robertson, Daniel Juckes, Marie O'Rourke and Renee Pettitt-Schipp
}

\section{'An ambiguous genre': thoughts on creative non-fiction and the exegesis}

\begin{abstract}
:
The requirement for separate creative and exegetical components by universities offering creative doctoral programmes is a largely accepted model in Australia. The Research Question Model adopted by Curtin University in Western Australia is an example of this. The parallel, 'independent' articulation of creative and academic responses is explored in this article by a supervisor and three $\mathrm{PhD}$ candidates all writing in the genre of creative non-fiction. We suggest that the boundaries between the scholarly and creative in creative non-fiction works are far from clear and that this reflects both contemporary non-fiction publishing and new movements in scholarly writing. We propose that Barthes's 'ambiguous genre', the essay, may be one useful way of conceptualising the non-fiction creative doctorate.
\end{abstract}

\section{Biographical notes:}

Dr Rachel Robertson is a Senior Lecturer in the Communication and Cultural Studies Department at Curtin University, Western Australia. She is the author of Reaching One Thousand, which was shortlisted for the 2013 National Biography Award, and was winner of the Australian Book Review Calibre Prize for Outstanding Essay in 2008. She is Reflections Editor of Life Writing journal and recently co-edited a collection of personal essays titled Purple Prose. Her research interests include life writing, creative writing pedagogy, Australian literature, critical disability studies and narrative nonfiction. Contact: R.Robertson@curtin.edu.au

Daniel Juckes is a PhD candidate at Curtin University, Western Australia. His research interests include nostalgia studies, Thing Theory, and autobiography. His writing has been published in Australian Book Review and Westerly: New Creative. Contact: daniel.juckes@postgrad.curtin.edu.au

Marie O'Rourke is a $\mathrm{PhD}$ candidate at Curtin University. Investigating the quirks of memory, her current creative work-in-progress is a collection of lyric essays pushing the boundaries of post-postmodern memoir. Her work has been published in Westerly, New Writing, $a / b$, TEXT, and the Australian Book Review. Contact: marie.orourke@postgrad.curtin.edu.au

Renee Pettitt-Schipp is a $\mathrm{PhD}$ candidate at Curtin University exploring ideas of connection and disconnection in Australian culture, informed by her experiences of 
living in the Indian Ocean Territories. Renee's recent work has been shortlisted for both the ACU poetry prize and the inaugural Dorothy Hewett manuscript prize.

Keywords:

Creative writing - Exegesis - Creative non-fiction - Essay - Barthes, Roland 


\section{Introduction}

We use this article as a way of thinking through the possibilities of the exegesis in the context of creative non-fiction writing and the particular demands of our own institutional home. Rachel, now a supervisor of the other authors, for her $\mathrm{PhD}$ wrote a set of autobiographical essays (later published as a memoir) and an accompanying critical exegesis, a model Krauth describes as the exegesis as 'parallel text' (2011: 9). It followed the Curtin University model of creative thesis, called the 'Research Question Model' and articulated by Barbara Milech and Ann Schilo more than ten years ago (2004). In this model, the creative work and exegesis 'can be seen as complementary articulations (outcomes) of a single research question (and related set of research objectives)' (Milech and Schilo 2004: np). Milech and Schilo argue that, in this model,

the written and the creative component of the thesis are conceptualised as independent answers to the same research question - independent because each component of the thesis is conducted through the 'language' of a particular discourse, related because each 'answers' a single research question ... In this way the two components of the creative or production-based thesis are substantively integrated, form a whole. (2004)

They suggest the key benefits of this model are: it resists the theory/practice divide; it accepts 'the authority, autonomy, languages and conventions of the disciplines that produce creative works and production pieces'; and it helps students understand research, use the investigative process in their creative production and talk 'with authority to different audiences' (2004). Milech and Schilo note that the Research Question Model is more challenging for students than what they call the Context or Commentary models, by which they mean models in which the exegesis is only required to provide either a context for or a commentary on the creative work (and which we consider are closest to Krauth's (2011) Reflective model). Of course, most universities require students to ask and respond to a research question but Milech and Schilo argue that the Curtin University model embeds a particular way of asking and responding to the research question which does not easily allow for an exegesis that is mainly context or mainly self-commentary.

The Research Question Model is still used for creative theses at Curtin University, and in most cases it continues to result in parallel works; for example, an art exhibition and a written exegesis. The University 'Guidelines for Creative Production Theses' still states that: 'A creative production thesis consists of two components - a a production (such as a novella, a series of paintings, a film, etc.) and a discursive text (called the exegesis)' (Curtin University 2015: 1). In creative writing, many of our theses consist of these two complementary items - a creative work and a scholarly exegesis (which usually falls between $25 \%$ and $40 \%$ of the total word count). However, there have been a small number of creative writing theses which have adopted a structure closer to Krauth's 'plaited' model (2011), where the exegesis and creative narrative are structurally interwoven, or a fully integrated thesis, which Krauth calls the 'blended' model and describes as putting 'the ingredients for artefact and exegesis into a bowl and mix [ing] them' (2011: 10). Obviously, it is easier to conceive of a parallel or plaited thesis using the Curtin Research Question Model as it implies two complementary 
answers to a single question. Using the model for a blended or integrated thesis is less straightforward.

A focus for this article are the issues that non-fiction works raise for the creative thesis and how we might understand such theses in the context of contemporary non-fiction publishing. Of the nine students Rachel now supervises, seven of them are undertaking projects that fall into the category of creative non-fiction. Their projects might be described as biography, family history, memoir, and writing about place, although these terms do not do justice to their diverse and exciting projects.

One of the key challenges for students working in non-fiction is that the distinction between creative work and scholarly work (or exegesis) can start to break down. When the voice used and the literature drawn upon in the creative work and the exegesis are very similar, it may be the case that the difference in projected readers is a way to distinguish the two parts of such a thesis, for example, a creative work pitched to a general 'public', and exegetical work aimed at scholars in the relevant field. Yet this distinction can also be contested. Krauth suggests the exegesis may be read as a preface and therefore targeted to the same readers as the creative work (2002), Bacon presents the exegesis as another creative genre (as in her 2017 discussion of exegesis as memoir), and Williams describes how the exegesis may be developed in diverse and innovative ways, such as an 'exegetical triptych' (2016).

Stephen Muecke, in his discussion of various 'publics', similarly renders any clear distinctions in readership as fraught. Muecke argues the 'reader' can no longer be seen as a stable entity, a 'public' which the writer seeks to court, influenced by a powerful literary cannon. Instead, Muecke argues, knowledge is 'disseminated to a broad public via ... specifically networked institutions' (2010: 3) such as universities, media outlets and publishers. This process is ongoing, enhanced by the role of social media, dynamic by nature and driven by a human desire for knowledge and the will to be moved. This 'networked set of social and institutional investment' (2), then, is no longer seen as predictable or given, and readership remains elusive as a means by which to distinguish the difference between creative and exegetical work.

To add to the challenges of distinctions around creative and exegetical work, we have found little discussion about the exegesis in creative non-fiction projects, or about the notion of how the two expected complementary forms (or responses to a research question) may be developed when candidates are writing the type of non-fiction that integrates both creative and critical (or creative and scholarly/exegetical) writing. And, as we shall see, the distinction between what is creative or critical writing comes into question when creative non-fiction works are examined closely. The two have always been strange bedfellows, and enforcing a split between the creative and exegetical seen in the light of a discussion of the hybrid nature of creative non-fiction - is questionable.

In this article, we explore these issues within the context of the Curtin Research Question Model and propose increasing the flexibility of our current guidelines and using the essay form as a way of conceptualising creative non-fiction theses. Input from colleagues and postgraduates was gained through a group discussion (held on 7 March 2017 and attended by seven doctoral candidates and six staff) and we partially formed 
this article around a series of questions Rachel posed by email to co-authors ${ }^{1}$. Because each author makes some comments about their own research work in this article, the plural 'we' here denotes the writing team. Individual contributions are signaled by indentation and italics with the individual author named.

\section{Current perceptions of the creative/exegesis divide}

The requirement for an exegesis (or equivalent) in a creative thesis from the academy's point of view is that it demonstrates that the creative practitioner has undertaken research and can write about it in an analytical, critical and theoretical way. Of all forms of creative writing, one might think that non-fiction demonstrates its research credentials the most overtly, though it doesn't necessarily self-theorise. However, we accept that there are different forms of research evident within non-fiction and that an ability to undertake archival research, for example, is not necessarily an indication of an ability to write critically and analytically about that research.

It was clear from our discussions that staff and doctoral candidates believe that both creative and scholarly knowledge production are important for doctoral work and that a separate but connected exegesis is a workable way of managing this. One doctoral candidate describes the exegesis as a theoretical discussion in indirect dialogue with creative work but suggests that, in reality, it is also a theoretical justification for creative work which is not seen as 'enough' in an academic sense. The perception that the exegesis in some way validates the creative production is shared by a number of doctoral candidates, echoing the published literature on the exegesis (see for example Webb and Melrose 2014, Williams 2016). Students also proposed that the requirement to separate ways of knowing and modes of expression suggested that, despite appearances, knowledge is still divided and prioritised within academia along familiar binaries, such as rational/irrational, objective/subjective, and masculine/feminine.

Our discussions also focused on the value of an organic approach to research and writing, where there is not necessarily a fixed form or structure at the start and the researcher is able to find the ideal form as the work develops. Williams, in 'The Performative Exegesis', recommends that 'students ... should allow for the myriad possibilities of the form of the exegesis, dictated by the nature of the artefact itself' (2016: np). This may be particularly important for creative non-fiction work, where the genre parameters are arguably less clear than those of other forms of creative practice, and even other forms of creative writing. This is not to suggest that fiction, poetry and other forms of creative writing are genres without ambiguity, but because of our position as creative non-fiction writers, it is easy to see our own forms as especially suited to more playful, ambiguous, hybrid outputs. Below, we show how students have adapted their approach to the creative thesis. This process of adaptation is clearly not confined to creative non-fiction practitioners but because of the reflexive, binaryreducing, embodied nature of the kinds of creative non-fiction we practice (discussed below), an organic and flexible approach has been very important.

Some students started their $\mathrm{PhD}$ with the intention of producing a parallel text thesis but, over time, believed that their research now demands a plaited or integrated approach. For example, Daniel's view is that the creative product plus exegesis model 
does work for his $\mathrm{PhD}$ project, but only if some flexibility is allowed in relation to the separateness of the two documents.

Through the research process - now three years of work - it has become clear that the two modes of writing, for me, are more than complementary: they are entangled, impossible to separate. In my project, the exegetical writing has bled right through the creative work, which has in turn informed, tempered, and changed the exegetical. It's tough to describe what this fusion looks like, but, for me, it's been telling to recognise moments in the text which demand a shift in register, and then an excavation either creatively or exegetically. I write reflexively, and find it more and more necessary to use a reflexive voice to position my observations of the scenes and even the structures of the memoir-in-progress. And - as a creative writer, focused on audience - there's a need to balance reflexive writing with more active elements. Words like 'symbiotic', 'organic', and 'reciprocal' spring to mind, but I would be hard-pushed to articulate the essence of each tipping point.

It is also difficult to articulate exactly how or when the two modes became entwined; it was, for a time, something I tried to resist: I wasn't confident that I could achieve the kind of fusion which a braided thesis demands, or, more practically, that that kind of work would be publishable at the end of the PhD process. But, after a couple of years trying (valiantly) to reinforce a binary approach to my research because of those worries, I began to understand how the nature of writing might be conceived as inherently braided. I also began to read more and more examples of hybrid works which could be classed as something like extended personal essays. As a memoirist with an interest in the shapes and structures of the past, much of my reading has been focused on historiography. Carolyn Steedman, in Dust, articulates some of where I think my motivation to interweave stems from: she says that the historian's 'massive authority' comes, in part, from a description (or at least a knowledge of, on the part of the reader) the journey of the researcher. Only then can a story be 'dictated to by ... sources, [and told] the way it has to be told' (2001: 145). Gaston Bachelard, in The Poetics of Space, suggests something similar: that 'We are never real historians, but always near poets' (1964/1994: 6).

Handing in a creative work and a separate exegesis would be impossible at this stage; submitting a hybrid work (in which the creative and the exegetical are fused) is my intention. My research project asks how it might be possible for creative writers to evoke the past. The creative component is a family memoir describing my relationship with my grandmother, as well as some of my family's history. A focus for the exegetical writing is how the use of the inanimate - objects, things, detritus - might aid in that evocation. By bouncing from objects, to thinking-about-objects, I have been able to braid creative and exegetical writing together. This hybridity is, I think, a direct consequence of the Research Question Model melding with creative non-fiction's essayistic methods.

The topic and theoretical approaches used by doctoral candidates also inform their position on the most useful relationship between creative and exegetical texts. Renee clarifies this in relation to her project.

Living on Christmas Island and the Cocos (Keeling) Islands had a profound impact on how I experienced my 'self' and the 'other' of people (such as islanders and asylum 
seekers), 'landscape' and the living and non-living world around me. This fundamental shift has driven my thesis and raised a series of questions around ways of knowing and seeing. One of the fundamental aims of my thesis is to question the traditional binaries of self/other, land/sea, Australian/un-Australian, as well as muddying the border between the seemingly discrete realms of the personal and political. Considering this, it soon appeared antithetical to the aims of my work to separate my personal story and theoretical reflections on the implications of this lived experience, so I began to write a thesis integrating the exegetical and creative discourses. I hope that in writing an integrated thesis I may be able to use form to mirror meaning; that the interconnection embedded in theories of deep ecology and ecofeminism will be reflected in the synthesis of 'ways of knowing' in the final, singular work.

Marie considers that her creative writing also tends to the experimental end of the spectrum, arguing for blurring of genres and definitions.

My project looks at how the structures and strategies of the lyric essay might work to represent narrated memory, exploring the neuroscience of memory to explain why and how the lyric essay works in similar ways to the process of remembering. Lyric essay is itself a hybrid genre, and much of my reading has inspired me to explore innovative approaches to the exegesis. Maggie Nelson - whose work I love - says she feels 'the same process of discovery of structure and genre when I'm writing "critically" or "creatively" - there's no difference for me anymore, if there ever was one' (2015: 1). That fluidity of form suits the discussion of fluidity in gender and family which The Argonauts pursues. But at present, my creative writing seems to be drawing out the split and multiple personalities or roles I assume in my life, and separation - into individual essays, into creative and exegetical - seems to suit the work I'm doing. I feel I'm yet to solidify a shape for my thesis overall, but I suspect it won't weave academic and creative together throughout. I like the 'instant' of experience that lyric essay allows and actively encourages, foregoing more traditional essayistic reflection and analysis. The exegetical research, of course, remains entwined with my creative practice, and I have been particularly interested in the way exploring the neuroscience of perception and memory has influenced my creative writing. Wearing both my creative and academic 'hats' simultaneously - as demanded by Curtin's Research Question Model - has enabled me to present my own recollections in a way that I argue is both affective and effective, and much more so than it would have been without those academic discoveries.

\section{Directions in contemporary non-fiction}

The three examples of projects presented by the authors of this article mirror the direction in which published non-fiction appears to be moving. Generic boundaries are increasingly being challenged in contemporary creative non-fiction. Recent work from authors like Mary Cappello, Maggie Nelson and Claudia Rankine is indicative of this new hybridity, and has proven how powerful and engaging a blend of theory, personal narrative, history and philosophy can be. For example, Rankine's Citizen: An American Lyric (2014) is a book-length work that might be described as cultural criticism, documentary, prose poem or lyric essay. Exploring identity, race and citizenship in America, it juxtaposes essay fragments, photography, public art and video scripts to 
amass a collection of microaggressions experienced by both Rankine and other persons of colour. The polyphonic nature of Citizen, the number and variety of text types and registers of language it contains, work to underline the omnipresence of racism. Breaking down generic boundaries, playing with form, contemporary creative nonfiction such as Rankine's is the sort of 'warm and active and realistically messy' prose (Retallack 2003, cited in Welch 2015: 124) that is proving so vital and challenging for readers.

Writers like Rebecca Solnit, W.G. Sebald and Helen Macdonald tell their stories using a mélange of memoir and criticism, combining fictional techniques with more traditional non-fiction techniques in their work. These writers are not just gaining critical success; they are also selling well. For example, Helen Macdonald's $H$ is for Hawk reached the Sunday Times best-seller list within two weeks of publication and won the 2014 Samuel Johnson Prize, the 2014 Costa Book of the Year Prize and the 2016 Prix du Meilleur Livre Étranger (Moss 2014, Penguin Books 2017). We suggest that Macdonald's book managed this popular success both because, and in spite of, the way it challenges the critical/creative binary exampled by the creative/exegesis split. The book is hybrid in form, combining a grief memoir, a biography of the life of the writer T. H. White, and notes on the history and methods of falconry. And while it is difficult to tease out which strand would be the most exegetical, for the purposes of brevity, the discussion of T. H. White displays many of the characteristics of textual analysis (in that it uses White's writing to decode aspects of his life), woven meticulously into the fabric of the book. Macdonald shifts seamlessly from her memoir to her story of White, maintaining tone and tenor, bouncing one from the other in a mode which might be described as fictocritical.

Owen discusses this oscillation between creative and critical in the academy and notes that academic work is provisional and part of a cycle of ideas. She says,

The problem of working without a dynamic sense of the university, working in fact, within a black-and-white, or creative versus academic, view is that neither of the polarised sides is challenged. Such a view leaves untouched ... the idea of the academic as objective observer. (2006)

She claims that 'Many academics use creative writing as one of their tools and others recognise that narrative and metaphor have always been an important part of academic expression' (2006), and we are certainly aware of academic colleagues in health sciences, anthropology, psychology and education at our own university who integrate creative writing techniques into their scholarly work. Similarly, Magee takes up the issue of reception and argues that plenty of scholarly works allow, even call for, complex and differing interpretations (2014), just as we expect of creative works.

Scholarly writing continues to change. Alongside fictocriticism, auto-ethnography, multi-modality and various types of performative essays, we see the introduction of the personal voice in disciplines that have, in the past, avoided this. As Ings notes in an exploration of the uses of typographical voice in exegeses, 'Currently within the academy there are contestations across diverse disciplines where researchers seek to extend the richness and clarity of their communicative potential' (2016). In Australia, the work of Ross Gibson provides an example of the changing face of non-fiction 
writing. Muecke's (2016) essay 'What is Fictocriticism?' quotes Gibson on why he chose to write 26 Views of the Starburst World in a fictocritical mode (rather than as a novel):

While a novel can be a marvel in the way it might encourage its readers to empathise with distinctive characters, this special affordance of the form can block other aspects of existence that are worth knowing too, crucial aspects such as conundrum and incomprehensibility as well as character-traits such as indeterminacy, multiplicity and mutability. (2016: xiii-xiv)

The questions Gibson is able to ponder in this book are complex and innovative. They are also accessible: the book is compelling, a work of art on its own, as well as a work of theory. Indeed, part of the point of Gibson's work is that he bridges perceived gaps between scholarly and creative production, and that he chases knowledge into more speculative realms. 26 Views of the Starburst World is described as both 'general nonfiction' and 'scholarly' by its publishers, UWA Publishing. Gibson himself (in a 2015 workshop) described his practice as an attempt to work in areas where conclusiveness is not possible, to encourage bafflement while maintaining rigour and producing an emotional payoff (2015). This melding of creative production and theory allows academic writing to be more accessible, and scholarly conversations to have an impact outside the academy. We suggest that urgent issues such as racism, social justice and environmental damage require researchers to step outside the readership of academic journals, and that creative writers are well-placed to write for this broader readership.

Gibson, Macdonald and Rankine represent a small but growing group of contemporary creative non-fiction authors which value flexibility and hybridity as well as scholarly rigour. In what follows we interpret this vein of creative non-fiction in light of Roland Barthes' description of the essay form as 'ambiguous' (1977: 3).

\section{The integrated creative non-fiction thesis as 'essay'}

Paul Williams asks, 'Why should the exegesis in a doctorate of creative arts use the language of expository or discursive prose when it has at its disposal the myriad voices and techniques of the very discourse it is attempting to justify?' (2016). We similarly question the need to separate the expository from the creative, most especially in the case of creative non-fiction projects. But we also want to move from thinking of the exegesis as a justification or explanation of the creative work. Creative discourse is a mode of intellectual inquiry and the production of more integrated theses may make it easier for those outside creative writing to recognise this. We ask with Magee, 'Why not converge energies upon the provision of one, singular work, on the grounds that it is possible to achieve the effects of poetic and novelistic art in works that are undeniable acts of scholarship as well?' (2014: 414).

We accept the need to meet institutional requirements. A non-fiction work accompanied by an exegesis highlights that creative practice is itself research and the product of research. An integrated thesis - a single work that is creative work, critical/analytical work and thesis - may demonstrate how creative practice is both research and product. 
Such a work avoids the problematics of the author of the exegesis appearing to speak with definitive knowledge about the creative component, which McNamara likens to asking the 'candidate to play analyst and patient simultaneously' (2012: 8). As Sempert et al. say, 'Creative and critical texts/artefacts do not always have to sit side-by-side, with a stated or suggested relationship: the two can work together, on the same page, methodology and output becoming one' (2017: 15).

A closer dialogue between creative and critical is reminiscent, we suggest, of the essay form, a form used by a number of the writers noted above (Nelson, Rankine, Macdonald, and Solnit, as well as, arguably, Sebald and Gibson), a form, furthermore, that is well known for its ability to allow for contradiction, paradox, ambiguity and the coexistence of seemingly binary positions (see for example Lopate 2013, Miller and Paola 2012, Singer and Walker 2013). It was Barthes who noted: 'Though it is true that I long wished to inscribe my work within the field of science - literary, lexicological, and sociological - I must admit that I have produced only essays, an ambiguous genre in which analysis vies with writing' (1977: 3).

Barthes' 'essays' are now viewed as scholarly texts. And Barthes, of course, is being playful in this quote (it is the start of his lecture on his Inauguration as Chair of Literary Semiology, Collège de France) and certainly more complex in his suggestion that analysis and 'writing' are opposed to one another than this extract suggests (as he notes later in this lecture). The essay as genre continues to confound by its transgression of boundaries and slipperiness of definition. Bensmaia argues that, even when considering only Montaigne - who he calls the ancestor of the form, both in English and in French (1987: ix) - and his essays,

we quickly become aware that the 'boundaries' of the essay were not only 'blurred' but were caught, rather, in a sort of perpetual mobility: no fixed sender, no unified subject or themes, and finally, no definite addressee ...We do not know if it falls within the realm of poetics, rhetoric, aesthetics, history, or philosophy. Or in all these realms simultaneously. (1987: 89-90; original emphasis)

Bensmaia argues the case that the essay is not one genre, nor a mixture of genres, but rather it complicates them (1997: 92). He then asks, what if 'the Essay belongs in the last instance to the genre of the Other by which the genres communicate with each other?' (92; original emphases). This, we suggest, is a wonderful way to read a creative non-fiction thesis - as a way in which genres communicate with one another. One doesn't have to take the argument quite this far, however, to see that the essay offers a useful way for us to think about the integrated creative thesis where exegesis and creative work are deeply inter-related and inter-dependent and which makes a contribution to (various types of) knowledge. We argue here that trends in scholarly debate and in creative non-fiction publishing suggest that a closer synthesis of the scholarly and the creative is already occurring and likely to continue. It seems to us a good position to allow doctoral candidates the flexibility to consider that their theses can be essays that are high quality aesthetic works, 'undeniable acts of scholarship' (Magee 2014: 414), in a form that is publishable. 


\section{Conclusion}

The reading and discussions which led to this article have made us more aware of the metamorphosis that continually occurs in creative writing, publishing and in creative arts scholarship. Within our own institution we see an opportunity to update our guidelines and expectations to encourage the flexibility we see happening elsewhere and which our doctoral candidates are ready to embrace. It has become clear to us that there are many ways of approaching creative theses across universities in Australia, and even within our university. As Bensmaia suggests, creative work can be both boundaryless and simultaneously perform work within different domains. For creative nonfiction writers, we propose that the essay form continues to offer a useful way to conceptualise parallel, blended and integrated theses. The fact that it is, we agree, a profoundly ambiguous genre (or even non-genre) seems to us a perfect fit with that ambiguous creature, the creative writer-academic, and that ambiguous artefact, the creative writing thesis.

\section{Endnotes}

1. How would you describe what an exegesis is, as the term is used at Curtin in creative practice PhDs?

Does the creative product plus exegesis model work for your research/PhD project? Why or why not?

Can you summarise your own research project and how the creative/exegesis structure will work? Does this fit nicely with the single Research Question that Curtin expects both to answer in complementary ways?

Are there any particular challenges or issues for non-fiction creative writing projects in relation to the creative/exegesis relationship?

If you could redefine what an exegesis might look like and its function and relationship to the creative text, what would that be? (Diagrams are permissible here!)

What models of academic writing inform your own writing? What scholarly conversations/debates do you want to contribute to?

What do you think is the future of the exegesis, or indeed of the creative writing doctorate?

Anything else you want to raise.

\section{Works cited}

Bachelard, Gaston, 1964/1994 The poetics of space trans. Maria Jolas, Boston: Beacon (1st pub. 1958)

Bacon, Eugen 2017 'The scholarly exegesis as a memoir’ New writing 14 (3), 386-97

Barthes, Roland 1979 'Lecture in inauguration of the Chair of Literary Semiology, Collège de France, January 7, 1977' trans. R Howard October 8 (Spring), 3-16

Bensmaia, R 1987 The Barthes effect: the essay as reflective text trans. P Fedkiew, Minneapolis: U of Minnesota P

Curtin University 2015 'Guidelines for creative production theses' Curtin University Research 1-4, at http://research.curtin.edu.au/postgraduate/current-students/policies-procedures (accessed 6 March 2017)

Gibson, Ross 201226 views of the starburst world Crawley, WA: UWA Publishing 
Gibson, Ross 2015 'The poetry of archives: workshop with Ross Gibson' WINTERarts 2015, Laurence Wilson Art Gallery, Perth: U of Western Australia

Graywolf Press 2017 'Citizen’ Greywolf press, at https://www.graywolfpress.org/books/citizen (accessed 19 March 2017)

Ings, Welby 2016 'The visible voice: typographical distinction in thesis writing' TEXT 20 (1), at http://www.textjournal.com.au/april16/ings.htm (accessed 9 March 2017)

Krauth, Nigel 2004 'The preface as exegesis' TEXT 6 (1), at http://www.textjournal.com.au/april02/krauth.htm (accessed 9 March 2017)

Krauth, Nigel 2011 'Evolution of the exegesis: the radical trajectory of the creative writing doctorate in Australia' TEXT 15 (1), at http://www.textjournal.com.au/april11/krauth.htm (accessed 9 March 2017)

Lopate, Phillip 2013 To show and to tell: the craft of literary nonfiction New York: Free

Macdonald, Helen 2014 H is for Hawk London: Jonathan Cape

Magee, Paul 2014 'What distinguishes scholarship from art?' New writing 11 (3), 400-16

McNamara, Andrew 2012 'Six rules for practice-led research' TEXT Special issue 14, at http://www.textjournal.com.au/speciss/issue14/McNamara.pdf (accessed 10 March 2017)

Milech, Barbara H and Ann Schilo 2004 “"Exit Jesus": relating the exegesis and creative/production components of a research thesis' TEXT Special Issue 3, at http://www.textjournal.com.au/speciss/issue3/milechschilo.htm (accessed 10 March 2017)

Miller, B and S Paola 2012 Tell it slant $2^{\text {nd }}$ ed, New York: McGraw-Hill

Moss, Stephen 2014 'Helen Macdonald: a bird's eye view of love and loss' The Guardian 5 November, at https://www.theguardian.com/books/2014/nov/05/helen-macdonald-interview-winner-samueljohnson-prize-falconry (accessed 17 March 2017)

Muecke, Stephen 2016 'What is fictocriticism' The Mother's Day protest and other fictocritical essays London: Rowman and Littlefield International, xi-xviii

Muecke, Stephen 2010 'Public thinking, public feeling: research tools for Creative Writing' TEXT 14 (3) at http://www.textjournal.com.au/april10/muecke.htm (accessed 15 May 2017)

Nelson, Maggie 2015 The Argonauts Minneapolis: Graywolf

Owen, Christine 2006 'Academic research and creative writing: redrawing the map and finding one's allies (and avoiding the Corbett phenomena)' TEXT 10 (2), at http://www.textjournal.com.au/oct06/owen.htm (accessed 10 March 2017)

Penguin Books 2017 ' $\mathrm{H}$ is for hawk' Penguin Random House Australia, at https://penguin.com.au/books/h-is-for-hawk-9780099575450 (accessed 17 March 2017)

Rankine, Claudia 2014 Citizen: an American lyric Minneapolis: Graywolf

Sempert, Mattie, Louise Sawtell, Peta Murray Sophie Langley and Craig Batty 2017 'Methodologically speaking: innovative approaches to knowledge and text in creative writing research' New writing 14 (2), 205-22

Singer, Margot and Nicole Walker (eds) 2013 Bending genre: essays on creative nonfiction New York: Bloomsbury

Steedman, Carolyn 2001 Dust Manchester: Manchester UP

Sturm, Sean 2012 'Terra (in)cognita: mapping academic writing' TEXT 16 (2), at http://www.textjournal.com.au/oct12/sturm.htm (accessed 9 March 2017)

University of Western Australia Publishing n.d. '26 views of the starburst world: William Dawes at Sydney Cove 1788-91', at https://uwap.uwa.edu.au/products/26-views-of-the-starburst-world-williamdawes-at-sydney-cove-1788-91 (accessed 29 May 2017) 
Watkins, Ross and Nigel Krauth 2016 'Radicalising the scholarly paper: new forms for the traditional journal article’ TEXT 20 (1), at http://www.textjournal.com.au/april16/watkins\&krauth.htm (accessed 9 March 2017)

Webb, Jen and Andrew Melrose 2014 'Understanding the value and the impact of the "shock": examining the creative writing doctorate' New writing 11 (1), 134-48

Welch, Tana Jean 2015 'Don't let me be lonely: the trans-corporeal ethics of Claudia Rankine's investigative poetics' MELUS 40 (1), at https://doi.org/10.1093/melus/mlu060 (accessed 9 March 2017)

Williams, Paul 2016 'The performative exegesis' TEXT 20 (1), at

http://www.textjournal.com.au/april16/williams.htm (accessed 8 March 2017)

\section{Acknowledgements}

Our thanks to the doctoral candidates and staff from Curtin University who attended our discussion on creative theses and helped us think through these issues, and to the anonymous peer reviewers for their comments. This article was, in part, supported by Australian Government Research Training Program Scholarships. 